\title{
Russia Amid Contemporary Global Challenges
}

\author{
Elena Blagireva \\ Russian State Specialized Arts Academy \\ Moscow, Russia
}

\begin{abstract}
The paper reviews the Russian economy's competitiveness amid global challenges, its strengths and weaknesses, and defines the key instruments ensuring sustainability of the economic growth and significant rise in the social living standards in the country. The quality factors of the economic upturn, ensuring high competitiveness of the country in general and of the most of Russian regions in particular, as necessary condition for their sustainable social and economic development, are of outmost importance.
\end{abstract}

Keywords-Competitiveness; economic growth; social living standards; innovations; investment

\section{INTRODUCTION}

Based on the official opinion, the World Bank experts prepared the economic report on Russia holding analysis of its economic situation and economic outlook. Amidst the global economic slowdown, the ongoing business depression in certain economies and recessionary processes in social area; it is necessary to search for economic optimization solution in Russia [22].

\section{GLOBAL RISKS AND COMPETITIVENESS}

With globalization, the qualitative (including structural) growth factors, enabling high competitiveness both of the country and most of its regions on global markets, become of prime importance since this is the necessary premises for their sustainable, social, and economic development and the attainment of high social living standards. It is important to stress that the Russian regions' competitive economic opportunities cannot be considered in isolation from the existing and competitive opportunities of the country's economy at large.

In this respect very interesting are the results of the global risk analysis and the competitive relationship of the economies, presented in The Global Competitiveness Report of the World Economic Forum (WEF) [12].

Summarizing their review, authors of the report point out that the ramifications of the year 2007-2008 financial crisis still have not been remediated, potentially lead to serious social unrest in the coming years. "The world encounters challenges that can be overcome only by long-range planning and cooperation between governments, business community and civil society," urge the WEF experts.

In accordance with the findings of the study undertaken in 2014 and 2015, the list of expected difficulties was topped by fiscal crises in leading global economies and in developed economies; unemployment and underemployment; fresh water deficiency; income inequality; climate change.

As in 2014, the WEF experts address in 2015 the increase of technological risks and cyber threats.

The WEF experts, for the first time, name among the risks the interstate conflict, expressed through such geopolitical instruments as trade sanctions, cyber threats and arms race. All this "is leading to the social brittleness, which, in turn, threatens the social stability".

In 2014-2015, Switzerland was for the sixth year in a row on top of the global competitiveness rating. Singapore comes second as in previous year and is followed by the United States, which have upgraded their rating from the fifth to the third place and stay the global leader in the supply of innovative products and services. Finland and Germany are on the fourth and fifth positions, respectively. Next among the top ten leading economies are Japan (6), Hong Kong (7), the Netherlands (8), the Great Britain (9) and Sweden (10).

The research shows that the competitiveness gap among the European countries persists against the backdrop of the European Union's efforts to address macroeconomic problems of the Euro zone. While the countries of North and West Europe have strong competitive positions, the countries of South Europe, such as Spain (the 35th position), Italy (49), Portugal (36) and Greece especially (81), which were seriously hurt by economic crisis and macroeconomic instability, are still lagging considerably behind, in spite of certain success achieved in their competitiveness in the preceding year.

Major developing market economies (BRICS countries) demonstrate various indicators. In spite of a slight rating downgrade, China leads in this group (29th position). As to other BRICS economies, only Brazil (48) upgraded its position this year, while South Africa (RSA, $52^{\text {nd }}$ position), India $\left(59^{\text {th }}\right.$ position) and Russia were very betters lightly.

The Global Competitiveness Index (GCI) synthesizes some hundreds indicators, united into 12 factor subscripts assessing competitiveness of economies worldwide, which present different levels of economic development. These factors include the quality of institutions, infrastructure, macroeconomic stability, public health and primary education, higher education and vocational training, quality of goods and services market, quality of labor market, maturity of financial market, technology level, and the 
market capacity, companies' marketability and innovative capacity.

Russia's standing today has bettered from the year-earlier period mostly due to the macroeconomic factors, and, in particular, thanks to the low level of its state debt and budget surplus. Notwithstanding that Russia's economy today is teetering on the edge of recession, its macroeconomic performance has an obvious advantage over some other countries' indices. The strengths of the Russian economy should include high popularity of the postsecondary education, relatively mature infrastructure and a considerable volume of domestic market. Russia's key natural resources endow, including mineral and energy resources, presents the country's crucial competitive advantage.

Capitalizing on Russia's competitive advantages, however, is stalled by government institutions' poor performance, insufficient innovative capacity, inefficient competition policy, underdevelopment of the country's financial market, weak competition on goods and services market, and the lack of investor confidence in the country's financial system. Among the key problems of Russia's economic development, as in the past year, the entrepreneurship names corruption, government failures and high tax rates as issues. All these factors result in a counterproductive allocation of the country's resources and hinder competitive power.

\section{THE POTENTIAL OF RUSSIAN BUSINESS}

However, it must be recognized, that Russia has failed so far to capitalize her high human and innovative potential as far as it is necessary. Hence, the researchers point to the modest positions of the Russian business on the list of the most competitive and dynamic corporations from comparable countries, the underdevelopment of small business, as well as to the low direct foreign investment, which is primarily made into extraction of natural resources and gaining access to domestic market.

It is against this background that federal agencies are taking necessary steps to promote competition in the Russian Federation. The significance of this public policy direction particularly is increasing amid the global crisis.

In 2009-2012, implementation of the competition policy had been carried out under the Program of competition development in the Russian Federation (hereinafter the "Program") and the Plan on its implementation, approved by the edict of the Government of the Russian Federation on May 19th, 2009 (reference number 691-r), suggesting a comprehensive set of measures and, in particular, the following primary targets [4]:

- General improvement of the competitive landscape through the reduction of unreasonable domestic and foreign trade obstacles, the establishment of mechanisms against overregulation, the development of transport, financial and energy infrastructure, and provision of its accessibility to market participants.
- Enhancement of the protection of competition against anticompetitive practices of the authorities and businesses through the improved antitrust regulation.

- Implementation of special competition development measures in certain economic sectors by way of removal of unreasonable domestic and foreign trade barriers, and application of tax and non-tax incentives and support tools.

In 2012, in the result of implementation of the Program, the government resolved to annul the Program and adopt the Action plan ("road map") called "The Development of the Competition and Improvement of the Antimonopoly Policies" (executive order by the Government of the Russian Federation dated December 28, 2012, No.2579-r). "The road map" suggests both the system-wide measures on Russia's competition development in 2013-2015 and the industry focus areas. It establishes a "revolving approach" to implementation of the competition development efforts that provide for forming the list of priority economic sectors and system actions on regular basis [8].

Directions of the competition development, which, on the one hand, were omitted by other "road maps", framed under the national business initiative, and on the other hand, are of special, systemic and substantial concern for the completion development, present the subject of the Action plan ("road map") called "Development of the Competition and Improvement of the Antimonopoly Policies", that is [8]:

- Including the competition development functions into the priorities of the executive authorities' action;

- Promoting competition in infrastructure sectors, including areas of natural monopolies;

- Reducing the public sector in economy;

- Introducing the best competition practices in constituents of the Russian Federation;

- Developing competition during procurement;

- Streamlining activities of entrepreneurship as part of the antitrust regulation;

- Raising the level of consumer rights protection.

Various key parameters, benchmarks and risks of Russia's social and economic development are presented in the Principal Directions of the Government Activity until 2018. The long-term challenges and their solution approaches will find reflection in the Social and Economic Development Strategy until 2030 [24].

It is important to understand that the country's competitiveness on the home market is reflective of the domestic economy's capacity to produce and consume goods and services in the setting of competition from similar foreign goods and services. Among the factors, conditioning its relatively low level, the special mention can be made of the underdeveloped competitive market environment, the monopoly abuse, the relatively high role of shadow economy, 
the low level and immature structure of actual demand, remaining gap between world and local prices of like products and services, and substantial deviation of current customs tariffs from those of the WTO member countries and other.

In this respect, it is evident that managing in the long view of the above said downsides of economic growth will let our country take the rightful competitive position in the system of world economy. Furthermore, the analysis of the Russian regions' competitive opportunities and the review of their efficiency in the process of current business function should factor in the primary areas of the national economy's forthcoming transformation, aimed at creating a preliminary basis for a sustainable growth and substantial rise of the living standards in the country. Institutions, infrastructure, innovations and investment should offer the basic implements, helping along this transformation.

At the same time, it is imperative to factor in, while carrying out the research, the governing criteria of competitive performance of any economic system in the world economy, namely, the level of labor productivity attained in this system. The importance of performance level of the national economy in the mentioned context was stressed by M. Porter, who, in turn, while describing Russia's present-day competitiveness, emphasized that the country "urgently needs development of her competitiveness at the level of companies, so to fully use her resource potential and establish a more diversified and dynamic economy" [19].

The problem of competitive performance at the level of companies is all the more relevant against the background, as experts think, of obviously exaggerated self-certification of Russian enterprises, as compared to their international assessment, which, at bottom, is due to the system of simplified criteria applied. However, Russian enterprises' competitiveness on certain market types varies considerably. Specifically, according to the research by the Primakov National Research Institute of World Economy and International Relations (IMEMO) of the Russian Academy of Sciences, just 3-5\% of domestic product is competitive on product markets of West Europe and North America. No less than $80 \%$ of the total produce has the necessary marketability on the domestic and CIS markets [17].

It should be pointed out, that under the Concept of longterm social and economic development of the Russian Federation until 2020, its overriding priorities set the strategy of development of Russia's and certain regions' specialization in the world economy on the basis of established most favorable conditions and premises for the development of potentially competitive industry sectors and producing units [2].

The objective of the concept of Russia's long-term social and economic development until 2020 is to find ways and means of securing on a long-term horizon (2008-2020) a sustained growth of the nation's wellbeing, the homeland security, dynamic economic development, strengthening of the positions in world community.
Following the official opinion given by the committees of the Organization for Economic Cooperation and Development (OECD), its council prepared the economic survey of the Russian Federation (January 2014), assessing its economic situation and drawing basic conclusions and recommendations. Structural reforms focused on the improvement of the business landscape is said to be the key to building the economic growth capacity and to the national economic resilience. This calls for an increase in the energy efficiency and labor productivity, based on competition, growth of investment and correspondence of professional skills and expertise to qualifications. Improvement of the business landscape presents an extremely crucial task [23].

Higher growth and its stability are impossible without improvement of the workforce and innovation policies [23].

As the Russian finance minister Anton Siluanov stresses, the greatest challenge now is to boost the competitiveness of the Russian economy, budget and financial policy, necessary to increase the country's economic weight in the world, to ensure regional leadership and to eliminate the gap with the developed economies [22].

In the environment of global competition and open economy, it is impossible to reach the level of the developed economies in terms of well-being and efficiency, not ensuring faster growth of those Russian economic sectors. This determines the country's specialization in global economic system and provide for maximal realization of the national competitive advantages.

Such approach requires implementation of a set of reforms, interdependent by resources, terms and stages, on the following directions.

The first direction suggests the development of Russia's human potential. On one hand, this includes creation of conditions favorable to the development of each man's abilities and improvement of the nation's living and social conditions. On the other hand, the competitive growth of human capital assets and social sectors of the economy, which are providing them.

The second direction sets the creation of a highly competitive institutional environment, generating the business activity and capital formation in the economy.

The third direction offers the structural diversification of the economy based on innovative technological development.

The fourth direction specifies the consolidating and widening on Russia's global competitive advantages in traditional areas (energy, transport, rural sector, processing on natural resources).

The fifth defines the extension and consolidation of Russia's external economic environment, effectiveness of its participation in global division of labor.

The sixth specifies the transition to a new model of spatial development of the Russian economy (formation of new centers of social and economic development, strengthening of the system of strategic regional development management, increasing the complexity and 
balance of the regions' development and distribution of labor force).

\section{CONCLUSION}

Finally, the move from the model of economic advance, based on the export of raw materials, towards the innovative model is also linked to building of new mechanisms of social development, based on the balance of business freedom, social equity and the national competitiveness.

\section{REFERENCES}

[1] Sergei Glaziev, The Strategy of Russia's rapid development amid global crisis. M.: Ekonomika, 2014.

[2] Granberg A.G., The principles of regional economy. Textbook, M.: The Higher School of Economics, 2006.

[3] Danilov I.P., The Russian regions' competitiveness (the theory and approach). M.: Kanon Plus, 2007.

[4] Mazilkina E.I., Panichkina G.G., The Competitiveness management. M.: Omega-L, 2008.

[5] Polynev A.O., The Competitive potential of the regions: Approach to analysis and ways of improvement. M.: Editorial, 2011.

[6] Polynev A.O., The Interregional economic differentiation: Approach to analysis and government regulation. M.: Editorial, 2011

[7] Porter M. The International competition. M.: Publishing House International Relations, 1993.

[8] Fatkhudinov R.A. Competitiveness: Russia and the world. 19922015., M.: Ekonomika, 2005.

[9] Fatkhudinov R.A. Competitiveness: Economics, Strategy, Management. M.: Infra-M, 2000.

[10] The Economic Politics, 2013,No.2, pp. 8-13.

[11] The forecast of the long-term social and economic growth of the Russian Federation until 2030 (prepared by the Ministry of Economy of Russia).

[12] The Decree of the Government of the Russian Federation No.1662-r dated 17.11.2008 "On the Concept of Long-Term Social and Economic Development of the Russian Federation Until 2020."

[13] The Requirements (technical standard) to the strategy of social and economic development of the constituent territory of the RF // The Ministry of the Regional Development of the Russian Federation. www.minregion.ru

[14] The Program of competition development in the Russian Federation. Adopted by the Russian government decree No.691-r as of 19.05.2009.

[15] Institute for Economic Strategies of the Russian Academy of Sciences. http://www.inesnet.ru/institute.

[16] League of Strategic Management, Appraisal and Account. http://www.russtrategy.ru.

[17] The Ministry of the Regional Development. http://www.minregion.ru.

[18] The Ministry of the Economic Development. http://www.economy.gov.ru.

[19] The Resource Center on Strategic Planning under the Leontief Centre. http://www.city-strategy.ru.

[20] The legal reference system Garant http://www.garant.ru.

[21] The legal reference system Konsultant Plus http://www.consultant.ru.

[22] The World Economic Forum Classification www.weforum.org

[23] Economic Reviews of OESDRU. The Russian Federation. Main findings and recommendations, January, 2014.

[24] Medvedev D.A., The New reality: Russia and global challenges. M.: Economy Issues, No.10, 2015. 